\title{
Joseph the Smith and the Salvational Transformation of Matter in Early Medieval Europe
}

\author{
Mary W. Helms
}

\begin{abstract}
In early medieval Western Europe, Joseph, the earthly father of Jesus, was identified occupationally not only as a domestic woodworker but also as a blacksmith, the most mysterious, powerful, and sacrosanct category of supernaturally endowed skilled crafting known to traditional nonindustrial societies. After reviewing skilled crafting and especially smithing as ritual processes, this essay considers typological identification of Joseph the smith as earthly parallel of the Deus artifex and as symbolic of the purifying (salvational) transformation of earthly matter (humanity) into a more rarefied (spiritual) state by fire as represented metaphorically by metallurgical processes. Aspects of the ideological climate of opinion encouraging such an identification in the early Middle Ages are also discussed. [St. Joseph, transformation of matter, smithing, early medieval cosmology, metaphors of salvation]
\end{abstract}

Mary W. Helms, Professor Emerita of the University of North Carolina at Greensboro, USA, is a cultural anthropologist interested in cosmology, cosmography, and political and ideological legitimation. Recent publications in early medieval cosmology and ideology include "Sacred Landscape and the Early Medieval European Cloister" (Anthropos 2002) and "Before the Dawn" (Anthropos 2004).

In Judeo-Christian sacred lore, as in numerous other religious systems, the ordered cosmos and its creatures are perceived to be the products of skilled crafting by an artisanal deity who first constructed the world by order and design and then created organic forms and beings and imbued them with life. ${ }^{1}$ Approaching creativity and artisanry from a more earthly perspective, traditional ideologies, including those of Judaism and Christianity, have long considered highly skilled human craftsmen to be imbued with uncanny, supernatural talents that, in turn, associate them with the original causal powers and creator-deities of the cosmos (Helms 1993).

This essay discusses Joseph, the earthly father of Jesus, as one representative of these extraordinary human artisans. Today Joseph is typically portrayed as a humble, domestically-oriented woodworker with an in-home workshop (Albright and Mann 1971: 172). In earlier Christianity, however, Joseph could be described more broadly as a professional woodwright, builder, stonemason, or blacksmith. I am especially interested in his identification as a smith in early medieval Western Europe (approximately the fourth through the eleventh centuries). During this time Joseph, as a member of the Holy Family, is a very marginal figure in formal Christian theology but, as a smith, he seemingly should stand in company with other metalworkers of lore and legend such as Hephaistos, Tubal-Cain, Wayland, and Volundr, among others, all of whom represent the most mysterious and sacrosanct category of supernaturally endowed skilled crafting known to traditional societies. This essay examines the role and character of Joseph in the contexts of traditional skilled crafting in general and smithing in particular and considers how identification of him as a smith can be understood within the ideological milieu characteristic of Western European Christianity during the early Middle Ages.

1 Genesis 1, 2; Niditch (1985); von Rad (1965). 


\section{Skilled Artisanry and the Gods}

I concur with Edmund Leach that sacred lore is mythic in content and that its personages and events do not record actual "history" per se but stand as metaphors, allegories, and symbols encoding more hidden ideological messages. An individual figure, like Joseph, is a dramatic character whose significance lies in his structural position or the qualitative value he signifies within the whole (Leach and Aycock 1983:2f., 8, 10, 107). From this perspective, one of Joseph's most salient features is the simple fact that he is most typically presented not as a peasant, or landowner, or merchant, or water carrier, etc., but as a professional craftsman, presumably signifying that the role and qualities associated with skilled crafting are fundamental to his ideological (mythic) significance and typological identity. This form of occupation, in combination with his further identification as husband of Mary and earthly social father and guardian of the youthful Jesus, clearly presents, on a very basic level of understanding, a structural parallel of Joseph with God, also a creator-craftsman and the divine father of Jesus. Yet Joseph's identification as an artisan may also imply much more.

Cross-cultural study (Helms 1993) has shown that, in nonindustrial societies past and present, professional artisanry is not merely a secular occupation but a value-laden activity that exceeds ordinary functionality because it is imbued with ideological significance and moral qualities that bespeak connections with the supernatural. Through their skillful activities artisans are both earthly correlates of creative divinities and vital intermediaries linking earthly society with the wider spiritual world. The heart of the matter is the widespread belief that skilled craftsmen are privy to the awesome secrets and mysteries (magic) of how base matter can be changed to form new and finer things. It is this knowledge and ability derived from supernatural sources that connects skilled craftsmen and their products with the omniscient cosmogonal creativity responsible for primordial origins and relates the ethereal, supernaturally informed "outside," or spiritual world, or condition of being with a more immediate, "earthly," or mortally human world, or condition of being. Not surprisingly, the skilled artisans who command such esoteric insights and talents and maintain such cosmological connections are themselves virtually always deemed to be different from ordinary persons and accorded distinctive social positions, sometimes negative, as dangerous and marginal outsiders, sometimes positive, as esteemed men of wisdom and exceptional ability.
These general points are well illustrated in the familiar mythologies of the ancient Near East and Mediterranean and in early Christianity and a few points may be noted as brief (and incomplete) examples. In the Hebrew Bible, divine creation, assisted by Wisdom (Proverbs 8.1, 22-31), is expressed in the phraseology of crafting using analogies with ceramics, sculpting, weaving, metallurgy, architecture, and building to describe and praise God's handiwork. Thus the skies are spread out "hard as a molten mirror" (Job 37.14-18), the celestial vault is structured with set beams and has doors and windows, the earth has foundations, measurements, and a cornerstone (Job 38.4-6; Psalm 104.3), and humanity is formed from clay or moistened dust or intricately woven like a fabric. ${ }^{2}$ Yahweh also imbues human artisans with the skills necessary for further constructions. In Exodus 31.3-6 he explains to Moses his selection of Bezalel (and also Oholiab) as builder and furnisher of the tabernacle: "I have filled him with divine spirit, with ability, intelligence, and knowledge in every kind of craft, to devise artistic designs, to work in gold, silver, and bronze, in cutting stones for settings, and in carving wood, in every kind of craft ... I have given skill to all the skillful, so that they may make all that I have commanded you ..."3

In the Hellenistic world, Plato advanced the idea of a creator god-cum-craftsman by his argument (in the Timaeus) that the great harmony and unity of the cosmos was evidence that such work had been planned before it was executed as an artisan plans the end product of his project before he begins it (Glacken 1967: 14, 44-46; Curtius 1953: 544546). In earlier Homeric epics, as well as in ancient Greek and also Roman society, supreme proficiency, cleverness, and cunning (mêtis) in human crafting again could be considered the direct result of inspiration from the gods, "as when a master craftsman overlays gold on silver, and he is one who was taught by Hephaistos and Pallas Athene in art complete, and grace is on every work he finishes." ${ }^{4}$ Consequently, to the layperson the talented artisan appeared to be a mysterious individual

2 Job 33.6, 10.9; Jeremiah 18.6; Psalm 139.15. - See also Glacken (1967: 155); Keel (1978: 204f.); Jacob (1958: 131, 142, 144-146); Graves and Patai (1964: 60f.). All Bible references are from the New Revised Standard Version of the New Oxford Annotated Bible (Coogan [ed.] 2001).

3 See also 2 Chronicles 2.13-14; 1 Kings 7.13-14; Sirach $38.1-8$.

4 Odyssey 6.232-234 (Homer 1967: 108). See also the Iliad 15.410-412 (Homer 1951: 321); Solon, quoted in Geoghegan (1945: 23). 
possessed of an uncanny control over materials of nature (Bultmann 1956: 104, 121). ${ }^{5}$

Both Hebrew and Hellenistic (Platonic) concepts of the world as harmonious cosmos indicative of a creative artisanal god are combined in the early Christian and medieval topos of the Deus artifex, fabricator of infinite skill and wisdom aided, according to some church fathers and apologists, by Christ as wisdom-like demiurge. Indeed, early medieval Christianity in general became preoccupied with the nature of original creation and the Edenic paradise, with the relationship of created things to the creator god and to each other, and with the means by which the original lost paradise could be regained. ${ }^{6}$ Fathers of the Church also regarded human artisanal knowledge as a form of wisdom and felt that, at times, the skilled craftsman was invested with such insights by God himself. ${ }^{7}$ Various forms of crafting, including woodworking and metallurgy, were among the diverse activities recommended by monastic founders to enrich the spiritual lives of monks (White 1978: 320, 323; Geoghegan 1945: 177, 178). Indeed, monasteries overall became "workshops" literally and figuratively. Benedict of Nursia, in chapter 4 of his famous "Rule," explicitly compares the cloister to an artisan's workplace since the entire monastic life was a spiritual and psychological creative process (Verdon 1984: 2; Kardong 1996: 80f., 195). ${ }^{8}$ To be sure, Thomas Aquinas (among others) cautioned that human creativity is of a far lower order than God's since humans can only employ already existing materials, such as iron, or wood, or stone, while God was the original creator of everything (Glacken 1967:274f.). Nonetheless, the mysterious expertise commanded by the skilled human artificer as master of the workshop evidenced a sequence from God's understanding to human intellect to expression in the arts and crafts; a union of the spiritual and the material in which God's creative intentions were expressed not just in holy words but also in more plastic media, continuing

5 See also Geoghegan (1945: 26, 14f., 80); Burford (1972: 12-15, 25, 27); Detienne and Vernant (1978: 11, 235f., $307 \mathrm{f}$.$) .$

6 Curtius (1953: 544); Blunt (1938-39: 53f.); Leclercq (1984: 68-71); Daniélou (1973: 180, 346-350); Dillon (1996: 366-374); Grant (1986: 158-160, 163, 165); Watson (1989: lxviii); Glacken (1967: 168, 172); Kelly (1978: 8387); Taylor (1961: 13, 14); von Rad (1965: 338f.).

7 Geoghegan (1945: 148). St. Augustine, for example, argued that human arts and skills were a product not of innate human worth but of the creator God's greatness and goodness (Glacken 1967: 196).

8 See also Geoghegan (1945: 218f.); Horn and Born (1979); Theophilus (1979). divine creation through human artistry that itself often evoked, in the untutored onlooker, a sense of the unexpected, the novel, the uncanny, the supranatural. ${ }^{9}$

\section{Joseph the Obscure}

At first consideration, extended discussion of Joseph's identity as a skilled craftsman during Christianity's first millennium does not appear promising. Early Christian sacred lore concerning Joseph is meagre. Only a few references occur in the canonical gospels, although more elaborated - though still limited - folkloric depictions of Joseph's life appear in six apocryphal sources (especially the so-called Birth and Infancy Gospels) dating from about the second to the sixth and seventh centuries, some of which were well-known in popular culture (Elliott 1993; Deasy 1937:4-15). Yet Joseph was largely neglected by the Western church itself. Official church documents relating to him are few, there was no public devotion to him, images were rare, no churches are known to have been dedicated to him before the 12th century, no relics were collected, and White (1978: 184) notes that, until the very late Middle Ages, "Joseph" was rarely used as a baptismal name in the West (Filas 1962: 24-35, 167, 285, 344; Lienhard 1999). To be sure, Church fathers recognized Joseph's social roles as spouse of Mary and legitimating earthly father of Jesus and lauded his character as a "just" (virtuous) man who was a faithful guardian and provider for his family. ${ }^{10}$ Yet there was little rigorous theological development of his nature by the early church.

This formal theological neglect would seem to be significant, however, in that it may have opened the way for invention and flexibility in whatever general interpretations and typologies might be accorded Joseph by laypersons, local clergy, and those in holy orders. For example, he began to receive positive attention in the early medieval monastic world and from certain church fathers as a participant (with Mary and Jesus) in the Christian work of salvation (Filas 1962: 488-491; Hale 1996: 103f.), a role expressed allegorically by (among other themes; Filas 1962: 490) his occupation, as we shall shortly see. Alternatively, although

\footnotetext{
9 Glacken (1967: 297f.); Kris and Kurz (1979: 53); Verdon (1984: 1); Leclercq (1984: 70f.).

10 Filas (1962: 106-109, 114f., 163, 201); Lienhard (1999); Meier (1991: 216f., 238); Hanson and Oakman (1998: 5457).
} 
the attitude of lay society toward Joseph in the early Middle Ages seems to be unknown, judging from later medieval materials Joseph, at least as a member of the Holy Family, remained incidental relative to the far greater interest in Jesus and Mary (Deasy 1937: 25). In this context it is noteworthy that, when Joseph appears in nativity plays and miracle plays of approximately the 12th-16th centuries, he is depicted either as socially marginal because of his Jewish identity or as representative of ordinary man, that is, a thoroughly human or "natural" and, therefore, somewhat ridiculous and definitely fallible human full of imperfections as indicated by his frequent representation as a coarse, comic fellow, often very old and fatigued, even senile (but married to a young woman and, therefore, also the cuckolded husband). ${ }^{11}$

It was also common in late medieval art and commentaries to identify Joseph with the theme of spiritual transformation from the Judaic Old Covenant (Synagoga) to the Christian New Covenant (Ecclesia) by casting him allegorically as representative of the Old Testament and Old Law ("the last and greatest of the patriarchs"; Hahn 1984: 520). ${ }^{12}$ In comparable fashion, he could be depicted in art as carrying a candle, symbolic of earthly and finite things destined to be outshone by the divine light of Christ (Schiller 1971: 73, 78f.). In short, in later medieval pageantry and art Joseph appears typologically as physically and behaviorally vulnerable Everyman and as belonging primarily to the non-Christian (or pre-Christian) and earthly or material world rather than to Christian mysteries of the purified and spiritual realm. These later medieval themes will also be helpful in probing the possible symbolic or thematic relevance of his occupation in the earlier Middle Ages.

\section{Joseph's Occupation: tektōn and faber}

In folkloric apocrypha, Joseph appears as a local woodworker who constructs plows and yokes, furniture, and domestic utensils or as a house builder who crafts roof beams, door frames, window lat-

11 Mellinkoff (1993: $267 f$., n. 148); Sheingorn (1996: 86); Deasy (1937); Leach and Aycock (1983: 51 f.); Filas (1962: 65f., 522-524). In nativity scenes of later medieval art Joseph is often portrayed as marginal to the event or as a very small, meaning ugly and ignoble, figure (Mellinkoff 1993: 80-82, 143f., 222-227; Wilson 2001: 35; Schiller 1971: 72f.).

12 See also Chorpenning (1999: 63-67); Gasnier (2000: $12-$ 15); Mellinkoff (1993: 48f., 74f., 79f.). tices, locks, and bolts. ${ }^{13}$ In the canonical gospels, Joseph's occupation is identified in two scripture verses. It is implied in Mark 6.3, where people in the synagogue at Nazareth, hearing Jesus preach, ask each other (in modern English translation) "is not this the carpenter, the son of Mary ...", Jesus the carpenter by implication presumably following his father's trade. In Matthew, written later than Mark and clearly derivative therefrom, ${ }^{14}$ the same incident is recorded in chapter 13.55 with a slight variation that explicitly states Joseph's occupation: "is not this the carpenter's son? Is not his mother called Mary?"

The critical point for this essay lies in the word used for Joseph's occupation in these two verses. In the variants of common Greek in which the gospels were originally written the term is tektōn. Tektōn is an ambiguous word in that it basically refers to skill in working with hard materials - wood, stone, horn, ivory, metal (but not, for example, wax or clay), the precise meaning being determined by context (Nineham 1963: 165). In general usage, however, tektōn is understood to refer primarily to an artisan "who works with wood, a carpenter" (Mounce 1993: 446). Likewise, the meaning attributed to tektōn in early gospel references in Greek, Syrian, Coptic, Armenian, as well as that understood by many Greek fathers, leans toward wood as the type of hard material involved. ${ }^{15}$ Some definitions emphasize construction and building (Morris 1992: 3; Danker 2000: 995) while still others simply note that the term has "a wide range of meanings from a shipbuilder to a sculptor, but it generally indicates a craftsman of considerable skill" (Albright and Mann 1971: 172f., nn. 55-56; Furfey 1955: 205).

Considered in light of these definitions and usages, Joseph appears as a skilled and thus highly knowledgeable craftsman who works with hard materials, perhaps especially wood. In addition, as tektön Joseph would also allegorically represent, in Christian cosmology and theology, the primordial building (construction) of the designed and ordered universe by a creator-craftsman also perceived as a master builder, even an architect. ${ }^{16} \mathrm{We}$ may presume to advance such exalted ideological

13 Filas (1962: 57 f., 63f.); Hock (1995: 49, 55, 129, 131). A possible alternative identification of woodworking as wood sculpting or carving does not appear in materials related to Joseph as far as I am aware.

14 Mark was written about A.D. 66-70, Matthew some time between A.D. 75-90.

15 Furfey (1955: 204-208, 214f.); Meier (1991: 281); Batey (1984: 249, 257, n. 2)

16 The English word "architect" derives from the Greek archi and tektōn, meaning master builder, chief artificer. 
and symbolic significance for Joseph's craft (above and beyond simple wage-earning work) since it was firmly believed by early church fathers well into the Middle Ages that every gospel word was true (the Bible being divinely inspired), had precise intent, and was filled with significant spiritual and/or allegorical meaning that went beyond the literal, indeed was sometimes hidden and not immediately perceptible to most people. ${ }^{17}$ We may assume, therefore, that the gospel description of Joseph's occupation as a skilled craftsman in hard materials was understood by Christian ecclesiastics and scholars to be not just a literal fact but also, and more importantly, metaphorically and theologically meaningful.

Such, indeed, was the case. Certain church fathers and medieval (and later) ecclesiastical writers, influenced especially by Ambrose, understood that Joseph's artisanal identity expressed a unique relationship between him and the creator God, allowing Joseph to take the place of God on earth typologically in this respect. As Ambrose put it (appreciating the power and enticement of allegory), even "if the human is not comparable to the divine, the symbol is nonetheless perfect" (quoted in Hahn 1984: 522, 517).

Thinking of the qualities usually ascribed to skilled artisans in general, several additional implications of Joseph's typological identity may also be suggested. On a more exalted note, as a godrelated craftsman, Joseph presumably could hold potential for extraordinary creational potencies of his own. As we shall see, this potential may especially inform his alternate identity as a smith. On a more mundane level, in his apocryphal role as local craftsman and head of a household, Joseph again appears as Everyman, for "in the early Middle Ages every countryman was perforce an artisan who had to make with his own hands all household objects from his home and clothing down to his pots and pans and agricultural implements" (Duby 1968: 153; Le Goff 1988a: 207). Such earthly materialism is not only appropriate for a woodworker but also will be directly applicable to Joseph as a smith.

Joseph's artisanal significance gained a different coloration when, in late Antiquity, the Greek gospels were translated into vernacular Latin, the language of the canonical works in the early Middle Ages (Berger 1893; Long 2001:2f.). In Latin biblical texts, the Greek word tektōn used to describe Joseph's occupation is replaced by the Latin term, faber. Mark 6.3 thus reads, in part, "nonne

17 Smalley (1964: 1, 8-10); Kelly (1978: 61f.); Simonetti (1994: 35, 42, 78, 89). iste est faber filius Mariae ..." and Matthew 13.55 reads, in part, "nonne hic est fabri filius ..." (Biblia sacra). Faber, like tektōn, basically means one who, with skill and ingenuity, works in hard materials. Thus (again like tektōn) faber can designate, rather ambiguously, a worker in stone (a mason), or wood, or metal (ores being initially stone-like). In order to clarify meaning, qualifying adjectives are sometimes used in general texts; for example, faber tignarius, a worker in wood, especially a builder; faber ferrarius, a worker in iron, a blacksmith. ${ }^{18}$ Often, however, the adjectives are omitted, leaving the context to define the meaning. Sometimes faber has simply been understood generally as an artisan who creates or fabricates objects, as in Deus faber. ${ }^{19}$ Not infrequently, however, in ecclesiastical contexts as well as in general medieval use (and also modern scholarship), faber in marked contrast with tektōn, ${ }^{20}$ becomes equated with one who works in metal, that is (in English) a smith. ${ }^{21}$

There are important points of contrast between woodworking and smithing as creational metaphors. Simply stated, woodworking presents creativity either as an emergence and defining of shape and form from formless material, as in wood sculpting or, in the context applicable to Joseph's occupation, as a form of construction, as arranging individual constituent pieces into an orderly pattern so as to form a new entity. Smithing, however, presents creativity as a transformation of material from one state of being (ore, stone) to another state of being (liquid metal). This change is affected by means of fire and also involves removal of impu-

18 Meiggs (1982: 360); Packer (1969: 42); Simpson (1968: 237).

19 Curtius (1953: 544-546); see also Chorpenning (1999: 73); Forbes (1964: 68); Eliade (1962: 101).

20 In addition to Latin translations, in the 4 th century the Greek gospels were translated by the missionary Bishop Ulfila (Wulfilas) into vernacular Gothic (an early form of Low German) for Visigothic peoples in Romania. In this translation, preserved in the early sixth century Italian Ostrogothic text known as the "Codex Argenteus," tektōn is translated as timrya or timrja; in modern German, Zimmermann, also with the meaning of Bauleute, that is to say, woodworker or builder (Heather and Matthews 1991; Friedrichsen 1926; Streitberg 1960: 188, 140; Thompson 1966). Other medieval Germanic gospels also tend to favor woodworking or building as Joseph's occupation or identify him as Werkmeister, master worker, master builder, or overseer (e.g., Tatianus 1966: 102, 491).

21 For example, Duby (1968: 20): "the faber, the specialized iron worker, the blacksmith," regarding Carolingian country life; Aelfric (1968), concerning the gloss on page 632, line 208, "smythe: Fabro"; see also Filas (1962:58); Forbes (1956: 60); Robins (1953: 84); Foster (1987 [1926]: 441), entry under "smyth." 
rities. Transformation by fire was a powerful soteriological metaphor for early Christianity apropos to the purification of physical being and the spiritual salvation of the soul (e.g., Eco 2004: 102, 103). Associating Joseph with smithing, therefore, also means associating him with the theme of salvational transformation and with transforming by fire (see also note 24).

Perhaps the most influential patristic commentary on Joseph's occupation in the early Middle Ages was written in the fourth century by Ambrose. As was noted above, and as Cynthia Hahn discusses at length (1984), Ambrose relates Joseph the artisan to God, the artisanal Creator of all things. More specifically, he describes the creating Father of Christ (God) as working both like a woodcutter and tree trimmer and by fire and spirit to fashion humankind for various uses and to soften and remove spiritual impurities of the soul (see full translation in Hahn 1984: 517). Hahn notes that not only Ambrose's typological comparison of earthly and heavenly artisanry (Joseph and God) but also his casting of such in the context of the salvation of the soul recurred frequently in early medieval patristic commentary and in the "Glossa ordinaria," 22 especially as exegetical commentary on Matthew 13.55 , the verse identifying Joseph's occupation (Hahn 1984: 517 and 1986: 58f.; see discussion below). Hahn also discusses an implied association of Joseph with fire in the 15th-century art (the Mérode Triptych) and in a liturgical office from 13th-century Liège. She then succinctly states that "Joseph's association with fire ultimately comes from the Gospel phrase, fabri filius, son of an artisan, commonly a carpenter or an iron-worker," adding that, in Ambrose's commentary, the artisan who softens souls with fire refers to a smith (Hahn 1986: 60; emphasis in original).

The identification of Joseph as a worker in iron, a blacksmith, to which Hahn refers was implied and occasionally explicitly stated in several early medieval contexts and it is to these materials, and to Joseph's general character if he is regarded as a smith, that we now turn, following Hahn's lead and encouraged also by the general comment by Le Goff that "the early middle ages tended to see [Joseph] as a ... blacksmith" (1988a: 207).

22 A 12th-century compilation of exegetical interlinear and marginal glosses on words and verses of Jerome's Latin (Vulgate) Bible that became the standard medieval Bible gloss throughout Latin Christendom (Smalley 1964: 56, 60$65)$.

\section{Textual Evidence for Joseph as Smith}

Evidence that Joseph was to at least some extent understood to be a smith in early medieval Europe appears briefly and rather in passing in at least three sets of texts: exegetical commentary (in Latin) by ecclesiastical writers based on, or obviously related to, Matthew 13.55 (occasionally Mark 6.3); explicit identification of Joseph as smith by two famous Spanish bishops, Leander of Seville and his brother, Isidore; various Anglo-Saxon texts from England, including the famous Lindisfarne Gospels.

The Church fathers whose exegetical commentaries are of interest include (though perhaps are not limited to) Hilary of Poitiers (4th century, d. ca. 367), Ambrose (4th century, d. 397), Peter Chrysologus (5th century, d. 454), and Bede (7th8th centuries, d. 735). We may begin by referring again to Ambrose, whose discourse on Matthew 13.55 (in his "Commentary on Luke") includes metaphors (noted above) by which the Father of Christ "works by the fire" and "softens the rigidity of souls in the fire of the spirit, and fashion[s] humankind" for various uses (Migne 184464: PL 15, sec. 1313.2, col. 1589). ${ }^{23}$ As Hahn indicates, such metaphors clearly employ the language of smithing and implicate Joseph in that same occupation (1986: 58). ${ }^{24}$

In his gospel exegesis, Ambrose made considerable use of the "Commentary on Matthew" written by Hilary of Poitiers a generation earlier (Watson 1989: ix). In this work, Hilary says that Jesus was the son of an artisan who conquers iron with fire (ferrum igne vincentis), melts away (decoquentis; as in melting away metals) all worldly (sinful) ways, and forms the mass (massam; a lump of something, especially of metal) into things useful for humans (Migne 1844-64: PL 9, chap. 14.2

23 PL refers to volumes of the Latin series of the Patrologiae cursus completus (Migne [ed.], 1844-1864). Since Migne's compilation is readily available and relevant passages in full context can be fairly lengthy, full Latin texts for the patristic sources noted in this essay are not reproduced here.

24 Ambrose's imagery of softening rigid souls and fashioning humans for different functions brings to mind commentary by Theophilus of Antioch, a second-century bishop of Jewish-Christian background, who, in a treatise ("Ad Autolycum"), explains the significance of the fall and of death with a metallurgical analogy within a salvational context. "Again, just as when some vessel has been fashioned and has some fault, it is resmelted or refashioned so that it becomes new and perfect, so it happens to man through death [when he is shattered so that in resurrection he may become morally sound]" (Rogers 2000: 47; Theophilus of Antioch 1970: 69). 
col.996-997). ${ }^{25}$ Approximately a century later, Peter Chrysologus brings smith-related metaphors to his own exegesis of Matthew 13.55 by saying, in part, that Christ was the son of the artisan who fashioned the world not with a hammer but with precepts and who forged (or fabricated) the mass of the world not with charcoal but with will (qui massam saeculi auctoritate, non carbone conflavit). ${ }^{26}$

Three hundred years later, Bede, under the heading "nonne hic est filius Joseph", discusses God as creator artisan and fire as manifestation of saving grace and extends a clearly smith-related metaphor involving precious metals to include a reference to the Old Testament book of Malachi, quoting 3.3: "and he will set as a refiner [conflans; sharper, melter, forger] and purifier of silver and will cleanse the sons of Levi, and refine them like gold and like silver" (Migne 1844-64: PL 92, col. 375). As with the previous authors, the fact that such exegesis, though brief, is introduced by reference to the text of Matthew 13.55 strongly implies that the commentary carries general relevance for Joseph's occupation, too.

Prior to Bede, two very famous sixth-seventhcentury bishops of Seville, Leander (d. 599/600) and his younger brother, Isidore (d. 636), straightforwardly state that Joseph was thought to be a smith. Furthermore, they say this in guidelines written for use by cenobitic monks and nuns, clearly indicating, it would appear, that there was nothing sacrilegious or scandalous about the idea. Leander's comment appears in his "De institutione virginum ..." (The training of nuns ...) in a discussion of how Joseph, as Mary's betrothed, was a just man but had to work for a living. Therefore, "it is read that he [Joseph] was a blacksmith [Certe faber ferrarius fuisse legitur]" (Leander of Seville 1969: 218; Migne 1844-64: PL 72, chap. 14, col. 887). The same point is made by Isidore when he discusses the role of work in his monastic rule for men: "Joseph justus, ... faber ferrarius fuit" (Migne 1844-64: PL 83, chap. 5, col. 873). Leander's and Isidore's monastic rules

25 Latin definitions are from Cassell's Latin Dictionary (Simpson 1968). Hilary is notable for his "allegorical ingenuity," a principle which his work did much to introduce into Western European thought (Watson 1989: viii). In light of his forthright description some modern scholars readily view him as one of several medieval writers who understood Joseph to be a smith: "It is true that St. Hillary, St. Bede the Venerable, and St. Peter Chrysologus tell us [Joseph] was a worker in iron" (Gasnier 2000: 29; see also editorial comment by Migne [1844-64] in PL 9, col. 996f., note g).

26 Migne (1844-64: PL 52, ser. 48, col. 334); see also discussion in col. 334-335 and Neale and Littledale (1883: 295). Charcoal was the essential fuel for smithing. were known to Spanish monasteries (Lawrence 1989: 53f.) and Isidore's rule seems gradually to have been disseminated outside of Spain, though it was not nearly as well distributed as many of his other works. Nonetheless, it is mentioned in ninthcentury catalogues of the monasteries of St. Riquier and of Fulda and several passages are cited in the mid-eighth century by Egbert, Archbishop of York, in Northumbria (northeast England), in a work of his own (Díaz y Díaz 1963).

It was also in Northumbria, on the small island of Lindisfarne, that Bishop Eadfrith, about A.D. 700 , made a copy, in Latin, of the gospels. Several hundred years later (about A.D. 950), a priest named Aldred prepared an interlinear gloss of the Lindisfarne Gospels; a running translation, word for word, in the Northumbrian dialect of Old English (Daniell 2003: 19-21, 34, 46). ${ }^{27}$ In this gloss, the earliest surviving translation of the gospels into any form of English, the Latin word faber (fabri) in Matthew 13.55 is translated as a choice of two possible Old English words, smiðes $t$ wyrchta, "smith or wright" (Hardwick 1858: 113). In two other Old English gospel versions with which the Lindisfarne gloss can be compared the relevant term is simply smiðes (Hardwick 1858: iii-ix, 112). ${ }^{28}$

In Old English, "smith" (like both faber and tek$t \bar{o} n$ ) could indicate a worker in metals or in wood or the general practice of fashioning or forging (Toller 1898: 889). In relation to Latin, "smith" replaces faber used in the general sense and faber ferrarius when referring to ironworking in particular (Lewis 1988: 37f.). Similarly, Old English wyrhta, when replacing faber in general, can define an artificer or fabricator, one who works at a trade, but also designates a woodworker when it replaces the more specific Latin faber tignarius (or faber lignarius) (Toller 1898: 1288f.); Lewis 2001:985f.).

In various other English texts, Joseph's occupation is sometimes that of smith, sometimes that of wright. For example, he appears as a craftsmanwoodworker both in an Old English (perhaps 11thcentury) version of the ninth-century apocryphal "Gospel of Nicodemus," where "Ioseph fabri filium" is translated as "wyrhtan sunu Iosepes"

27 Old English or Anglo-Saxon, a Germanic language, was spoken in most of England (it had three main dialects) from the mid-fifth century until the twelfth, when it merged with Norman French to become Middle English (Daniell 2003: 22).

28 Ms. no. CXL in Corpus Christi College, Cambridge, and the Hatton Ms. in the Bodleian Library. The Rushmore Gospel, originating in Ireland around A.D. 800 and glossed shortly after the Lindisfarne Gospels, also uses "smith" (Long 2001: 39; Hardwick 1858: 113, bottom). 
(Cross 1996: 3, 140, 141), and in the very popular late medieval "Mirror of the Blessed Life of Our Lord Jesus Christ" (Hogg and Powell 1989: 81; Ragusa and Green 1961:xxii-xxiv, 32, 64). Alternatively, Joseph is a craftsman-smith in various other late medieval nonbiblical religious or moralistic texts (see Lewis 1988: 38, left col., sec.b), such as the 14th-century "Stanzaic Life of Christ" (Foster 1987 [1926]: $191 \mathrm{f}$. [line 5688], 441) and William Caxton's 15th-century English version of the "Legenda Aurea" (Caxton 1931: 69). However, in the "South English Nativity of Mary and Christ" (ca. A.D. 1400), the author, apparently concerned with setting the record straight, firmly states that Joseph "was a carponter [sic] and no smith" (Lewis 1988: 37, sec. a). Returning to biblical works, the earlier versions (ca. A.D. 1380-1384) of the socalled Wyclif Bibles (the first complete translations of the entire Bible from the Latin Vulgate into various local forms of English grammar and vocabulary) use "smyth," with "carpenter" as an alternative, for Joseph's occupation, while the later version (ca. 1388) uses only "carpenter." 29

Most of the Latin and Anglo-Saxon texts described above derive from two distinctive regions located on the western edge of continental Europe and orthodox Latin Christendom. The Lindisfarne glossing and Bede's commentary come from Northumbria and various later texts are also from England, while the monastic rules of Leander and Isidore come from Spain and Hilary is associated with Poitiers in extreme western Gaul, across the Pyrenees from Spain. Both Anglo-Saxon England, especially Northumbria, and western Gaul and Spain were regions where early medieval orthodox Catholic Christianity was heavily influenced by other religious systems, both pagan and Christian, creating distinctive religious environments. ${ }^{30}$ Much of Anglo-Saxon England and especially Northumbria was strongly influenced by Celtic Christianity introduced by Irish-trained monks, who countered strong pagan traditions by preaching in towns and villages and establishing monasteries, includ-

29 Forshall and Madden (1850: 37, 102); see also Bosworth (1907: 71, 191, 582); Daniell (2003: 76-85). Wyclif Bibles were used extensively in England for 150 years until the arrival of William Tyndale's first printed New Testament, translated from the Greek, in 1526 (Daniell 2003: 66, 85, 88). Tyndale translated tektōn as carpenter.

30 There is also evidence of direct communication between England (and Ireland) and Spain and the Loire region of western Gaul in the early Middle Ages in matters scholarly and ecclesiastical (and otherwise), though nothing that casts further light directly on Joseph's occupation. See MayrHarting (1991: 85, 198, 124); Hillgarth $(1962,1984)$; Herren (1980); Cunliffe (2001: 477-481). ing that at Lindisfarne in mid-seventh century, while in general coexisting comfortably both with significant pre-Christian elements and with Benedictine missionization. The world of Celtic Christianity, which differed from the Roman Church on various issues of theology, liturgy, and other points, also was largely isolated from continental religious trends for a considerable period of time (ca. A.D. 450-600). ${ }^{31}$ The Spain of Leander and Isidore was in the process of officially changing from Visigothic Arianism to Catholic Christianity and Arianism was of deep concern to both bishops and also to Hilary of Poitiers (Collins 2000: 53; see below). Popular religious beliefs were also widespread in the Peninsula. Indeed, popular and pagan beliefs and practices were so abundant that learned churchmen often preached in more rustic "country" speech when addressing the populace and even when writing for the edification of monks. Even biblical literature was notably "soaked with local color" (Berger 1893: 7, 8). Some forms of church organization and monastic life were also distinctly regional and it further appears that (not unlike Celtic Christian Britain) there was little wider European interest in affairs in Spain at the time such that "she seems curiously isolated from the rest of the Church." 32

Although recognition of Joseph as smith constitutes a rather minor piece of biblical lore, the extent of whose distribution in medieval Western Christendom is, so far as I am aware, unknown, it is at the very least noteworthy that these two regions where that identification is clearly found are also characterized by distinctive ideological regionalism and especially by mixed religious traditions that very likely supported a considerable range of ideological precepts and strongly colored the overall intellectual climate within which Joseph's identification was expressed. Let me be clear. I am not suggesting here that Celtic Christianity or Arianism per se occasioned Joseph's identification as smith (but see further discussion below); rather it is the fact of religious diversity and admixture that is important, for beliefs held by orthodox Latin Catholic Christians, other variants of Christianity, and pagan traditions all came to be thoroughly intertwined in early medieval Western Europe in general (see

31 Herren and Brown (2002); Dunleavy (1960: 17-25, 95, 111, n. 1); Godfrey (1962). - The Celtic Church proper read biblical texts in Latin and, though there are glosses of the New Testament in Old Irish from the second half of the eighth century, I have not been able to consult them. See Berger (1893: chap. 3); Richter (1988: 12, 69).

32 Hillgarth (1962: 169, 170; 1980; 1984:2f., 6); Collins (2000); Díaz (2001). 
below). As a result, considered more broadly, it appears likely that Joseph's identity as smith can be reasonably understood as generally reflecting or responding to diverse Christian orientations combined with long-standing and persisting non-Christian beliefs concerning the qualities associated with craftsmen who practiced metallurgical skills.

\section{The Qualities of Smiths}

Joseph's identity as a smith places him in the illustrious company of fabled smiths of the ancient Near East, Mediterranean, and northern Europe as well as numerous others of Asia and Africa, all of whom exhibit exceptional suprahuman qualities and abilities. Since, to the best of my knowledge, there are no further details from the early Middle Ages specifically regarding Joseph as smith, further assessment of associated ideological and cosmological qualities that may have accompanied that identity must be inferred from a review of how Old World metalworkers, especially blacksmiths, were usually perceived and by considering the roles and qualities accorded practicing smiths in early medieval Europe.

Traditional smiths throughout Europe, Africa, and Asia were long recognized as masters of an extremely esoteric and supernaturally potent craft by which they completed the creative work of the gods. In practice, their perceived supernatural abilities, which could include powers of healing and divination, often positioned smiths as close seconds to shamans or as shaman-like themselves. ${ }^{33}$ The most salient feature of this extraordinary identification is recognition of both smith and shaman as Masters of Fire, where fire or (magical) heat is considered a primary agent either of original creation or of the transformation or perfecting of things. It is a short step to further associate smiths philosophically with life and life-giving principles and to regard the smithy as a sacred space where generative processes are evidenced. ${ }^{34}$ More specifically, smiths were viewed as collaborators who accelerated and perfected nature's production of ores and minerals. Ores were long and widely regarded not as inanimate material but as organic entities imbued with life that slowly grew naturally in the earth. The smith's furnace became the womb in which ores completed their gestation and the production of

33 Forbes (1964: 69, 73, 80); Eliade (1962: 81, 87-96, 99, 106; 1964: 470-474); Edsman (1949: 98); Childs and Killick (1993: 325); Robins (1953).

34 Eliade (1962: 19, 21, 79-86, 107); Forbes (1964: 75f.); Robins (1953: 26). metals under the care of the smith was interpreted as akin to giving them birth. ${ }^{35}$ Since the esoteric and generally secret knowledge that allowed the smith to assist nature by transforming stone with the power of fire was thought to be derived from and to involve the supernatural, the actual processes of smithing were typically accompanied by rituals and protective charms and the smith himself could maintain a state of ritual purity while the work period was in effect. ${ }^{36}$

Given the ideological potency of the operation and for practical reasons, too, smelting furnaces were often set up in unsettled territories close to mines or to forests where charcoal could be made. Similarly, forges were often located on the edges of communities where the searing heat and sparks, smoke and steam, and pounding noise of the "magical" work were less disturbing to the general populace. ${ }^{37}$ The nature of the work, its marginal location in uncultivated wilderness or on the edge of settled villages, and its ritualistic ties to the supernatural meant that smiths themselves virtually always and everywhere were perceived as ambiguous or liminal figures standing betwixt and between cosmological realms, linking humanity with the gods (or with the powers of the wilderness) and employing an almost god-like (or demonic) capacity to control and transform matter. Their extraordinary qualities and status are evidenced (in part) by their frequent portrayal in lore and legend as stigmatized in some manner, either behaviorally (e.g., as antisocial men or men without typical families) or physically (e.g., as dwarfs or as lamed or otherwise crippled). ${ }^{38}$

Many of these general features were characteristic of European smiths during the early Middle Ages, where they served at all levels of society. ${ }^{39}$ Aristocratic courts and manors employed blacksmiths in the production of a wide range of agricultural items and military wares, ${ }^{40}$ including

35 McNutt (1990: 255); Childs and Killick (1993: 326, 328); Forbes (1964: 76); Eliade (1962: 8, 42, 46f., 57, 79).

36 Forbes (1964: 71f.); Eliade (1962: 54-61); Childs and Killick (1993: 327f.).

37 Forbes (1964: 69); Childs and Killick (1993: 325, 327); Treister (1996: 79).

38 Forbes (1964: 52f., 69, 72); Eliade (1962: 89-91; Morris (1992: 87f.).

39 For a general overview of medieval metallurgy and metalworking see Nef (1987); Walbank (1987); Singer et al (1956); Addison (1908); Forbes (1956); Verhulst (2002).

40 Ironworking was basic to weaponry requiring good cutting edges and in the production of armour. See the vivid description, by a ninth-century monk of St. Gall, of the fearful psychological impact of just the appearance of the ironwielding army of Charlemagne and of the glittering, metal-clad king himself outside the walls of Pavia in 773 (Addison 1908: 124; White 1962: 40). 
the all-important iron-headed axe, an absolutely essential tool (and qualitatively powerful symbol) for transforming the medieval landscape for human use, and, by the late ninth and early tenth centuries, the equally important shoeing of oxen and horses. ${ }^{41}$ Ecclesiastical life needed metal smiths to embellish church interiors and provide liturgical vessels and implements of precious metals and to manufacture wrought iron grills and, especially, iron and bronze bells believed to be imbued with the power to dispel evil. 42

Monasteries included workshops and forges for smiths as part of their general communal organization or utilized the services of smiths in nearby villages. ${ }^{43}$ Some monks, even great abbots, also worked at smithing themselves. ${ }^{44} \mathrm{~A}$ few ecclesiastical smiths were even canonized. Most notable here is St. Eloi (Lo, Eligius), seventh-century master metalworker, bishop, and founder of monasteries, who became a famous figure in medieval lore for his extraordinary powers and resurrectional miracles. Variations on St. Eloi legends involve Jesus and St. Peter as well a various smiths as Masters of Fire in transformation-by-fire tales involving the "resurrection" of human beings, who are successfully changed from old age to youth by the fire of the forge when Jesus or St. Peter do the forging but suffer far less desirable fates when smiths attempt to emulate. 45

Ordinary villagers relied on small, portable smithies for simple, everyday objects and the open-walled and roofed forge in a nearby woodland could serve as an informal social center, too (Robins 1953: 83, 85; Nef 1987: 703). Smithies were also frequently located at crossroads for the convenience of travelers requiring that horse be shod (Farmer 1992: 206). Since the crossroads was itself a supernaturally charged site, the smith may well have been implicated in the complex symbolism and periodic folk rituals identifying that locale as a cosmologically critical omphalic meeting

41 Verhulst (2002: 77-79); Robins (1953: 80, 84f.); White (1978: 77, 110, 140f.); Thomson (1956: 390).

42 Addison (1908: 116, 145); Forbes (1956: 64); Theophilus (1961: xxxviii, 155); 1979: 79f.; White (1978: chap. 6).

43 Horn and Born (1979: 190-198); Robins (1953: 81); Verhulst (2002: 72, $77 \mathrm{f}$.).

44 E.g., Dunleavy (1960: 26, 61); Sarton (1947: 663); Addison (1908: 16-20).

45 Farmer (1992: 156-167); Addison (1908: 57-62); Robins (1953: 71-73, 113); Edsman (1949: 115-118). See also St. Dunstan, tenth-century Benedictine monk and abbot and Archbishop of Canterbury, who allegedly defeated the devil with a pair of red hot tongs when tempted by the demon in his forge (Farmer 1992: 138f.); Addison (1908: 110f.); Robins (1953: 66-71). point were strangers met, cosmological realms intersected, and the wider supernatural world (including the dead) encouraged the local and the living. ${ }^{46}$ Indeed, it can be argued that the very presence of the extraordinary smith and the smithy (itself a hierophanic place of fiery transformation) helped define the crossroads as a cosmologically significant location (Eliade 1959: $21 \mathrm{f}$., 63; Brown 1947: 34). Smiths who worked as smelters in forests and woodlands had the added quality of association with a cosmographical setting that was defined ambiguously as both ecologically beneficial and a frightening, qualitatively wild and spiritually unredeemed haunt of demons and temptations; a wilderness inhabited by equally anomalous solitary and socially marginalized persons, including charcoal burners, hermits, outlaws, and hunters, as well as smiths (Le Goff 1988b: 47-59).

Reflecting the mysterious nature of his fiery craft, the qualitatively charged setting where he worked, and the magical spells that assisted him at his labor (Eamon 1983: 173), the early medieval blacksmith himself has been described as "an extraordinary figure, almost a sorcerer" (Le Goff 1988a: 206); a highly skilled craftsman who was "a sacred being" (206) and who, especially as Master of Fire, had not yet lost the traces of exceptional socioreligious status that gave him common ground with mystics, magicians, and shamans (Forbes 1964: 72, 97; Eliade 1962: 106f.). He could be a feared figure, identified with the devil (also associated with mastery of fire; Eliade 1962: $105 \mathrm{f}$.). Alternatively, he could be positively valued as a personage whose work reflected the salvational process of purification that transformation by fire could achieve (Edsman 1949).

Purification by fire carried potent symbolism. In Christian hagiographies and martyrologies the purification of living stone in the furnace by fire was symbolically compared with human salvation by fiery martyrdom (as in early Christianity), when the physical body died and was dissolved and then renewed and transformed to purified celestial glory. ${ }^{47}$

46 Churches dedicated to St. Giles, a patron of cripples and beggars and also of blacksmiths, also often stood at such road junctions. Giles, an immensely popular medieval saint, was originally a seventh-century hermit living in Provence who (according to his hagiography; see Farmer 1992: 205f.) once healed a crippled man with his cloak and was himself accidentally crippled by an arrow shot by the king while hunting deer. Giles' injury is interesting since, in lore and legend, smiths not infrequently are portrayed as being lame or crippled in some fashion (for example, Hephaistos, Ilmarinen).

47 Edsman (1949: 96-98, 166-171): see also Eco (2004: 102, 103); St. Eloi legends above, and note 24. 
It should also be remembered that, in the early Middle Ages, advanced technological processes in general were accorded exceptional spiritual value. They were regarded as part of the pursuit of the mystical restoration of humanity with Christ and evidence of the divine likeness of humankind as, with mysteries of craft and acknowledging the close relationship between craft and spirituality, earthly artisans imitated and extended the works of nature, giving shape and form to otherwise base matter. 48

\section{Joseph as Smith}

Opinions about the qualities represented by Joseph as smith in the early Middle Ages very likely would have varied according to social class and profession. As we have seen, Christian patristic writers appreciated both the soteriological theme of purification and transformation by fire, for which the creative smith's work became a ready metaphor, and the parallel between Joseph the skilled craftsman and God the cosmic artisan. Judging from Leander's and Isidore's comments, monks and nuns would have understood Joseph's smithing as a positive valuation of the dignity of honest work and approved the transformation metaphor as informing the parallel process of controlling and altering their own imperfect humanity into a higher spiritual form. If the general role and qualities apparently accorded the smith and smithing in early medieval secular life are taken as guides, we can further postulate that, for unlettered laypersons (and probably also some local clergy), Joseph as smith would have been accorded mystical powers and the resulting ambivalence that ordinary people feel for that which surpasses their understanding and for those who exist more or less on the margins of social and ideological propriety. At the very least, as a smith Joseph would have been regarded as an uncommon man; a type of "other" with skills and qualities differing from those of ordinary persons and ultimately suggestive of supernatural (divine) association.

In Christian context, supernatural association related Joseph to the creator god of Genesis. But early medieval Western European culture also preserved a rich pagan tradition as foundation to its Christianity (e.g., Russell 1994). It is likely, therefore, that the populace of both high and low estate fur-

48 White (1978: 101, 185f.); Glacken (1967: 295); Hugh of St. Victor (1961: 29f., 55f., 75, 76, 191, n. 64); Le Goff (1977: 81 f.). ther grounded their interpretations of Joseph within pre-Christian lore and traditions that had long recognized pagan smiths as extraordinary beings with fearsome magical powers. It would be informative to contrast the assorted lore about Joseph in general with characteristics of legendary pagan smiths not only in Europe but also of the Mediterranean and Near East. These could include the Greek Hephaistos, the Hebrew Cain and Tubal-Cain, and, in Europe, the Celtic Goibniu, Germanic Volundr, Anglo-Saxon Wayland, and Scandinavian Ilmarinen. ${ }^{49}$ I conducted a detailed review of this sort focusing on structural elements of myths as we know them today. However, full presentation of these materials here would be lengthy and, indeed, that study requires a separate essay. Yet it may be noted, in summary form, that when the exploits and personal characteristics of these legendary smiths are compared, the mythic smiths overall are seen to be associated with a number of major cosmological contexts. These include the original creation of life and/or architectural building or other construction projects; earthly materiality (as represented by the products of their artisanry); travel or life outside ordinary society and the liminal crossing of cosmological boundaries; unusual or less than ideal circumstances of birth; transformative fires, purification or salvation, and immortality; magic in general; behavioral or physical stigmas. When any and all events and characteristics pertinent to Joseph are considered, Joseph as skilled craftsman and as earthly parent of Jesus is found to fit these distinguishing features of legendary smiths to varying degree but all-in-all remarkably well. (Significantly, the few features that are not clearly applicable to him do fit the figure of Jesus, reminding us of the wording of Mark 6.3, in which it is Jesus who is identified as the skilled craftsman)..$^{50}$

The early medieval identification of Joseph as smith, and thus presumably as uncommon liminal figure and cosmological or ideological "other" who transforms earthly matter into finer purer forms,

49 The literature on these legendary smiths is extensive. The following sources provide an introduction and much basic information: Gantz (1993); Leach (1969); Lönnrot (1963: 48-50, 328, 355f.); Morris (1992); Robins (1953).

50 In early medieval Europe, pagan Germanic beliefs about smiths might have been particularly influential in informing concepts about Joseph as smith (see discussion below). In addition, in the Christian ecclesiastical world and in popular religious plays and pageants (e.g., Murdoch 2003: 90-93) the figure of Cain/Tubal-Cain is given considerable, though generally negative, attention. See discussions in Graves and Patai (1964: 109f.); Mellinkoff (1981: 103, n. 1, chap. 5); Morris (1992: 85, 96f.); Cohen (1999: 28-32, 35); Emerson (1906). 
is also not incompatible with later medieval representations of Joseph in the context of his relationship with the rest of the Holy Family. As we have seen, Joseph was typically portrayed as marginal or as "other," being representative of the Old Testament or of pre-Christian Jewishness, as well as symbolic of "natural" man or Everyman marked by the frailties and failings of specifically earthly physical life and indicative of materiality rather than of spiritual, meaning Christian, values. In a number of respects this later medieval interpretation parallels the suggested early medieval view of the extraordinary smith as a mysterious outsider who lives and works on the edge of acceptable society and associates with unsavory characters who populate the spiritually unredeemed wilderness. As the later medieval Joseph represented non-Christian/pre-Christian Jewishness, so the early medieval smith represented an occupation with deep roots in non-Christian/pre-Christian (pagan) European (and Mediterranean and Near Eastern) belief systems. The association of Joseph with earthly existence and materiality in later medieval art and pageantry also parallels the basic association of the smith with the raw materials (stones, ores) of the earth. In addition, the theme of transformation and purification of being is fundamental to both smithing and the soteriological purpose of the incarnated godchild who is the sole raison d'être of the Holy Family, including Joseph.

In brief, as a liminal and anomalous smith and/or as member of a liminal and anomalous family, Joseph can be defined with the mixture of the positive and the negative that, by definition, is always applied to liminal persons (see also Mellinkoff 1993: $267 f ., n$. 148). In the limited official Christian ecclesiastical purview, Joseph the obedient earthly husband-father was an extraordinarily kind, just, and salutary parent and guardian. However, Joseph the skilled smith, like Joseph the Jew, presumably also remained grounded in and defined (and limited) by pagan or pre-Christian ideologies and, like aging Everyman, was involved most directly with the earthly and material aspect of the human condition.

\section{Early Medieval Cosmologies}

In addition to the general role and character popularly assigned to the early medieval smith, there are several other broad elements of both orthodox Catholic theology and the mixtures of Christian and pagan beliefs constituting early medieval versions of Christianity that may have facilitated iden- tification of Joseph as a smith. These include the general cosmological orientation of canonical early medieval Catholicism, Arianism, belief in magic, and the general nature of Germanic Christianity.

During the early Middle Ages, Latin Christianity's cosmology and theology strongly emphasized absolute first principles of original creation and sacred beginnings (i.e., the Hexaemeron; Glacken 1967: 247). ${ }^{51}$ The nature of all reality, all nature and all history, was directly referred to that inception as well as to the ultimate eschatological end, after which eternity would once more be realized. Similarly, God was a distant creator deity made accessible to humans by a glorious Christ who was also interpreted theologically as true divinity and powerful pantokratōr; a cosmic suprahuman often depicted iconographically as supremely calm, dignified, and majestically triumphant. ${ }^{52}$ It would befit this cosmological climate if the earthly parents who harbored the youthful incarnation of the glorious Christ-God would also be portrayed as exceptional, suprahuman, liminal figures who surpassed the ordinary to exemplify absolute qualities of perfection, power, and creativity in various ways. The mysteries of Jesus' conception and birth to a virgin of impeccable rectitude obviously identify such qualities in Mary, ideological descendant of diverse pre-Christian female divinities, who was further elevated as Queen of Heaven in early medieval theology (Warner 1976: chap. 7). Recognition of Joseph as a smith, presumably well versed in the mysterious supernatural skills of his creative craft, identifies them in him, too.

Indeed, metalworking would seem far more appropriate than woodworking as a metaphor for the first principle alpha and omega of original cosmic creativity and ultimate eternal salvation because of its greater technical mystery, that is to say, the uncanny process by which the smith's furnace produces a change of state in stone, transforming it to

\footnotetext{
51 For medieval thinkers, the Hexaemeron (the six days of creation) was the vital point at which the natural emanated from the supernatural such that the material world was henceforth subservient to the spiritual. Brehaut notes that the Hexaemeron fascinated medieval thinkers as the doctrine of evolution intrigues modern scholars (1912: 79f., 69).

52 References for early medieval cosmology and theology are many, but a list of useful sources can be found in Helms (2002: 438, n. 4). See also Katzenellenbogen (1967); Brehaut (1912: 79f.); Hillgarth (1980: 31); Chaney (1967: 73). This theological perspective began to change markedly during the 11-12th centuries, when Christian piety brought God down to earth and gave greater consideration to the humanity and "historicity" of Christ as well as to more practical exploration of God's creative plan as seen in nature (White 1947: 429; Ross 1997).
} 
flowing liquid to be followed by a further stage in which hardened metal is again softened and made pliable by fire and forged, without breaking, into new forms, all in a dramatic atmosphere of excessive heat, flying sparks, dynamic hammering and eruptions of steam from quenching water that can readily appear as a microcosmic glimpse of supernatural, indeed cosmic, creative potency. To be sure, woodworking can convey notable imagery of creational abilities, both in the realization of sculptural images by carving and also when, in construction, new organization and design emerges as disparate pieces of wood or other building material are carefully trimmed and shaped and fitted together; the skilled earthly master builder continuing the work of the primordial architect who first designed and organized the constituent units of the universe. It is easy, therefore, to appreciate the appeal of Joseph as woodworker and especially as master builder.

Yet woodworking per se lacks the ultimate quality of mystery in processual technique - the amazing plasticity and durability of metals and the astonishing transformational change of state that smithing exploits and that underlay the long association of metals with magic (Salzberg 1991:9). Wood and procedures for woodworking have less inherent potential for evidencing seemingly supernatural (magical) qualities and powers, though wood, and especially trees, the archetype of fruitful vegetation (life), have long been accorded their own, very fundamental symbolism in Near Eastern, Mediterranean, early Christian, and European pagan traditions (e.g., sacred trees and groves, the cross, trees of life, etc.; Helms 2002: 442f.; Meiggs 1982: 22). Nonetheless, within the context of skilled crafting, while processes of woodworking can accommodate and enhance by degree the basic nature of raw wood by giving it representational form by carving or shaping pieces to conform to a new construction, metalworking not only accommodates but also appears to transform and rarify the inherent basic nature of ores - and thus seemingly magically manipulates original creative processes and powers - by inducing fundamental changes in kind (stone to liquid to solid metal) in the nature of the materials with which it works.

Early medieval Catholicism had good reason to explicitly emphasize principles of creation and the full divinity of its pantocratic celestial Christ, and thus to be especially open to creational symbols. The highly influential "heresy" of Arianism, though sharing a great many commonalities with Catholicism, challenged the inherent divinity of Christ by affirming that, though an inspired prophet, he was essentially a human creature (Watson 1989: xi; Chadwick 1967:249). It seems noteworthy that three of the above texts identifying Joseph as smith were written by bishops who strongly and actively opposed Arianism's influence in the church. Leander and Isidore of Seville were dedicated supporters of Catholicism at the time when Spain's Visigothic Arians officially converted to it. Several centuries earlier, Hilary of Poitiers had also tirelessly and famously opposed Arianism and staunchly defended Catholicism and the divinity of Christ. ${ }^{53}$ That such respected members of the ecclesiastical elite identified the earthly father of Jesus as a smith, that is, presumably as a creatively and mysteriously transformational and liminal master craftsman, would seem to be directly consistent with, and supportive of, the anti-Arian position stressing the first principle nature of Christ as full and creative divinity.

Joseph the mysterious, magical smith was also appropriate for Christianity's growing accommodation with traditional paganism in Europe; an adjustment culminating in an indistinguishable mix of Christian and non-Christian beliefs and activities. ${ }^{54}$ One of the most firmly established principles of this early medieval ideological amalgam, accepted by laypersons and clergy alike, was firm belief in magic; that is to say, belief that certain individuals had the ability to impose their will on external forces of the world by mysterious (secret) means. Technology had long been regarded as a category of mysterious magical acts in which supernatural powers dominated natural forces, and skilled craftsmen, who could manipulate nature's secrets with spells and charms as well as with empirical knowledge that they also kept secret, were easily apotheosized as creative magi. ${ }^{55}$

Technology's aura was well exemplified by the smith (Eamon 1983: 173), and conceiving of Joseph as magus would have been entirely consonant with a milieu in which Catholic missionary monks and clergy accepted such non-Christian magic as was deemed helpful in strengthening Christianity's acceptance within still largely pagan cultures. Presenting Jesus not only as the divine son of the original cosmic creator but also as incarnated into the family of a skilled magus would be readily

53 Hilary's position on Arianism postdated his writing of the "Commentary on Matthew." However, he apparently was well aware, even at that time, of heresies impugning the Godhead of Christ and firmly states his support of that orthodox doctrinal position (Watson 1989: vii-viii).

54 Hillgarth (1980: 51 -55); Jones (1963); see also Barb (1963) and Dickie (1995).

55 Eamon (1983); Eliade (1962: 101); see also Kris and Kurz (1979: chap. 3). 
understood by a populace whose Christianity was strongly informed by earlier non-Christian personages, rites, and beliefs and who accepted the presence of the marvelous on an everyday basis. ${ }^{56}$ For that matter, in the New Testament, the apocryphal accounts, and the early church in general, Jesus himself was regarded not just as a divinity but also as a miracle-working magician and thaumaturge, contributing to the rise, thorough entrenchment, and prominence throughout the early Middle Ages of "a Christian form of wonder." 57

Joseph's typological characteristics presumably were also significantly influenced by the overall Germanization of Christianity which eventually became normative (and especially influential as folk religion) throughout much of early medieval Europe (Russell 1994). Among other features, the Germanic impact on Latin Catholicism fostered not only a heavily magico-religious perspective but also a heroic, power-oriented ethos and worldview that emphasized human life, temporal powers, and rewards in this world and respect for nature's powerful and equivocal forces. Germanic Christianity also was greatly concerned with the historical drama of Christ's earthly life and focused on the power of the Christ-God to effect this-worldly life more than on eschatological concerns and soteriological aspirations (Russell 1994: 6f., 17, 23, 188f.; Le Goff 1977: 173f.). Orthodox Latin Christianity, of course, had a different focus. In terms of Josephrelated symbolism, as we have seen, the aspect of Joseph's smithing that appealed to patristic fathers mainly involved the powerful metaphorical imagery provided by metallurgy's transformation by fire wherein raw, imperfect earthly matter could be changed into a new and purified substance of value, analog for the overwhelming change that awaits the faithful, who will ultimately be transformed and redeemed from sinful physicality to cleansed spiritual perfection and eventual eternal life.

In contrast, it seems reasonable to suggest that, as a more worldly Germanic-Christian context developed, the metaphorical emphasis of transformation by fire would have shifted from the ultimate

56 Barb (1963: 107, 115, 123); Flint (1991): Boenig (2000); Jones (1963: 18-20); Chaney (1967); Russell (1994).

57 Flint (1991: 33); Smith (1978); Herren and Brown (2002: $160-165,173 \mathrm{f}$.). "Good" magic (miracles or mysteries) was understood to further the relationship between people and the supernatural in positive terms that improved human life. Magic to control weather, solve everyday problems, or effect cures was acknowledged and sometimes even practiced by Christian clergy, though many church spokesmen disapproved (Barb 1963: 106f.; Hillgarth 1980: 47; Flint 1991; Eamon 1983: 181) soteriological and eschatological perspective that ends the process to greater concern with the raw material that begins both the salvational and the metallurgical transformational processes. In other words, Germanic Christianity may have particularly emphasized the earthly (material) pole of the matter - transformation - spirit continuum. If so, Joseph as blacksmith would connote not only creational Master of Fire but also chthonic Master of Matter (Vries 1974:51), an interpretation in accord, too, with long-standing Germanic and Germanic Christian interest in the supernatural powers accorded material objects, such as the magical swords, spears, helmets, etc. that legendary smiths could craft (e.g., Russell 1994: 43).

If Joseph as a smith were to become particularly associated with the materiality of his craft, it is easy to extend his general identification with matter beyond occupation to later medieval themes in which he is related to symbols referencing materiality per se or appears as earthly Everyman burdened with humanity's foibles, failures, and physical weaknesses. ${ }^{58}$ However, a connection with matter is also strongly implied in some of the symbolic meanings long accorded the raw materials with which Joseph was always associated as a craftsman: wood and iron.

\section{Base Matter: Wood and Iron}

To identify Joseph as a craftsman in some form of hard material is to place him in company with all the artisans, including smiths, heralded in Ecclesiasticus as "maintain[ing] the fabric of the world" (38.34). In the Near East, Mediterranean region, and traditional Europe, wood and iron in particular long maintained that fabric as raw materials essential to human survival. ${ }^{59}$ Wood was so fundamental a substance that it signified matter in general in the ancient world; the Greek word for "matter" (hyle ; that which was given form in the universe) was simply the word for wood or lumber ${ }^{60}$ and the Latin term materia (matter, material, stuff of

58 Possibly a somewhat parallel process may have encouraged a change from an earlier identification of Joseph as master builder or overseer, suggestive of God as a divine designer, as in Ulfila's Gothic translation of the gospels (see note 20), to his later medieval portrayal as a domestically-oriented woodworker with modest in-home workshop. See, for example, Hahn (1986: 55); Stratton-Pruitt (2002: 33, 34, 43).

59 Forbes (1958: 14-22); Glacken (1967: 318-325, 336f.); Meiggs (1982).

60 Doresse (1960: 80, n. 23); Bultmann (1956: 128); Smith (1968: 639); see also Sambursky (1956). 
which anything is composed) was also the word for wood used in construction (Meiggs 1982: 359; Hughes 1983: 440). In the European Middle Ages, "wood (together with the produce of the earth) was a material so precious that it became the symbol of earthly goods" (Le Goff 1988a: 204). Le Goff, who notes the early medieval tendency to see Joseph as a blacksmith, also sees in the later medieval identification of him as a woodworker "the incarnation of the human condition in the wooden middle ages" that may have manifested "medieval feeling about raw materials," including both the valuing of earthly goods and the need for redemptive rising above them (1988a: 207).

Iron also has long been accorded symbolic and metaphorical significance, often as a substance which is in some manner base, meaning qualitatively lacking or negative in attributes. In classical literature, coarse iron ore, which derived from the wilds of the mountainous wasteland (Brown 1947: 38, 46), was ranked qualitatively as the lowest metal (following gold, silver, and bronze) and associated with humans (following gods and spirits; Treister 1996: 120). Centuries later, in northern Europe, the Kalevala describes iron in broadly similar terms as a personified substance originally living in the wilderness and, therefore, wild, untamed, and dangerous (Lönnrot 1963: 48, lines 89100). In the European early Middle Ages, Isidore of Seville described iron as hard and cold (Brehaut 1912: 155f.) while Bartholomew Angelicus (13th century), in his discussion of "the Properties of Things," declared iron to be of the earth, though capable of change by hammering (Addison 1908: 4, 110). Similarly, Roger Bacon, ranking minerals and metals on a scale of pure to impure, clean to unclean, puts iron at the bottom of the list as unclean, impure, and altogether too "earthy" (Bacon 1992: 4, 6). In the color-imagery of the early Christian tradition and the early Middle Ages, the darkness of a lump of iron ore was a significant factor in its "baseness" since it signified the absence of any element of godly (spiritual) light or luminosity and thus represented the purely physical world, death and night, and/or spiritual humility (Dronke 1974: 64, 76, 79).

Both wood and iron were further believed to be imbued with fundamental chthonic life force, wood because it derives from living trees rooted in the earth and iron because it was obtained from equally "living" stone also rooted in the earth (Plumpe 1943; see also Murray 1975: chap. 6). As a living force, however, wood is subject to eventual death (rotting) and decay while iron is more durable (everlasting). Iron also was long accorded exceptional magical power useful for either good or evil purposes but, in any event, requiring care in management (Eliade 1962: 27-30). ${ }^{61}$ As this essay has repeatedly emphasized, iron's greatest manifestation of seemingly magical potencies (and its point of greatest contrast with wood, both materially and symbolically) lies in its capacity to be transformed by heat and hammering from a lesser to a greater (stronger) and purer material, whereas when wood is affected by fire, no matter how spectacularly, it ultimately loses worth and is consumed (dies), reduced to ash and charred remains. ${ }^{62}$

Nonetheless, during metallurgical purification and transformation, the role of ore is as the basic raw material, the "irregular Lump" of matter (Robins 1953: 101), that begins the process of change. Thus, iron ore can stand as metaphor for whatever is to be (or could be) transformed into a finer product, whether it be physical, mortal, sinful ("impure") humanity, as in early medieval Christian exegesis, or part of the lump of base black matter that initiated the ideologically related and soteriologically informed laboratory processes of the alchemist in the later Middle Ages and thereafter. Indeed, iron's most widespread medieval appreciation as base or primary matter may lie with late medieval alchemists who, as honorable scholars and experimental artisans, correlated earth with iron. Alchemists continued the long-standing interests of smelters and smiths in living matter. As Masters of Fire they, too, sought to understand and control the magico-religious transformation of living stone, sharing with Christianity (for many were God-fearing men, even men in holy orders) a commitment to seeking and perfecting means to achieve the spiritual perfection of earthly material. ${ }^{63}$

61 To note a few examples, iron was not allowed in the construction of Moses' sacrificial altar to Yahweh and generally was not permitted in Greek sanctuaries or in certain religious ceremonies in Rome (Robins 1953: 30f.; Forbes 1956: 59; McNutt 1990: 217-219). In the European early Middle Ages, and long after, iron's inherent magical potency determined whether it should be used to cut certain plants and warded off the devil, witches, and storms (e.g., Flint 1991: 321, 324; Robins 1953: 28). According to Robins, in Poland, when the initial introduction of iron ploughshares was followed by bad harvest, farmers blamed the iron and went back to using wood (1953: 31).

62 Charcoal is the exception to this statement, but charcoal, though highly useful, seems to lack symbolic significance in traditional lore.

63 Alchemy arrived in Western Europe during the 11-13th centuries and flourished for several centuries thereafter. For an introduction to its theory and development see, among others, Jung (1953); Hopkins (1934); Eliade (1962); Salzberg (1991). 


\section{Conclusion}

In the cast of liminal personages enacting Christianity's central theological drama, the role of Joseph was long the most subdued. Yet Joseph filled an important structural position in this sacred myth as earthly analog of God the Father and God the Creator. As such, he supplied vital functions in the canonical narrative as Jesus' genealogical and Mary's social legitimator and protector. In addition, Joseph grounds the saga of the Holy Family within the wider existential mysteries of universal creation and cosmological transformation as these are manifested by processes of skilled crafting. In so doing, he stands typologically, in Christianity, as archetype of earthly artisans, manipulating tangible matter and intangible supernatural potencies to create new forms.

In cross-cultural perspective, the archetypical skilled craftsman has long been the smith, an extraordinary figure closely related traditionally to the shaman in ideological and cosmological significance. It is not surprising, yet also fascinating, that during a still formative period of its Western European development, Christianity to at least some degree associated the earthly father of its liminal god-child with this most mysterious of liminal enterprises. It is also interesting, though perhaps merely coincidental, that this early medieval identification was paralleled by a notable silence in the official church in general about Joseph as a figure in Christian theology. Conversely, judging by exegetical commentary, the metaphorical value of the process of transformation and purification of matter by fire was appreciated by at least some early medieval church fathers since it evoked the spiritual purification of humanity and the soteriological progress of the soul which lay at Christianity's theological core.

Such imagery was nothing new. It was widely used well before the early Middle Ages in preChristian Hebrew traditions and appears after the early Middle Ages in late medieval (and later) Western European intellectual contexts. In "The Forging of Israel," Paula McNutt (1990) explores in detail metallurgical imagery and the symbolism of iron technology in the Hebrew Bible, including the metaphor of transformation by fire as it relates to the ancient Israelite understanding and presentation of its sacred history (e.g., Egypt as a womb-like "iron furnace" whence Israel will be transformed, strengthened, and reborn socially and spiritually as a people). Over a millennium later, Western European alchemists, in spite of official opposition by the church, sought, with frequent reference to the opening chapters of Genesis (Eliade 1962: 225; Patai 1994:18), to continue and hasten nature's (God's) processes of maturation and to perfect the spiritual growth of base matter (living stone) by probing, in the laboratory, into processes of creative transformation as they occurred in the hermetically sealed retort, where changes in the color of metals (indicative of the qualitative presence of light) would reveal the degree of spirituality achieved. ${ }^{64}$

Joseph as a smith in the early Middle Ages, therefore, is not an anomaly. Rather, appreciation of the cosmological and theological metaphors expressed by metallurgical processes and thus, presumably by extension, identification of Joseph himself as a smith, contained intrinsic worth. Though specific data are woefully limited, it can be suggested that this identification was not only ecclesiastical metaphorical hyperbole, or simply an accident of linguistic translation, or just useful accommodation with pagan beliefs, or helpful refutation of heretical opinion, or part of a ubiquitous belief in magic, though to varying degree all of these may well have been involved, but also part of on-going Judaic and Christian and pagan traditions (held in common with numerous other societies, too) involving the mysteries of material transformation that the uncanny knowledge and exceptional skills of the smith made manifest and controlled.

It is also tempting to suggest that, while canonical medieval Christianity appreciated and appropriated the ideological power of the transformational metallurgical process, it was hesitant to openly acknowledge the potency of the smith as an extraordinary liminal figure himself, for Joseph's alternate identity as a woodworker has always been far more acceptable, perhaps at least in part because both woodworking and woodworkers were inherently less mysterious entities and thus could be more readily co-opted or "domesticated" into the service of promoting the greater liminality and divinity of the central person of Jesus. ${ }^{65}$ Smiths do not labor quietly and unobtrusively, sidelined in small residential workshops, as Christian lore and iconography have typically represented for Joseph as woodworker. Smiths and their smithies are be-

64 Appreciation of the cosmological power and mystery of smithing continues to be evoked in literature into the present day. To note but one example, consider the poem titled "The Forge" by the Irish writer Seamus Heaney, which describes the obliterating darkness of the smithy, the noisy creative work of the earthy smith, and, set at the center of it all, the ritualistic anvil, "immovable; an altar" where the smith expends his talent (1980: 49).

65 Parallels between wood's ability to die and decay and Everyman, as represented by Joseph, as a mortal form that dies and decays may be relevant here, too. 
yond the ordinary and set apart as focal and as wondrous in themselves. Ultimately, especially as the human component of Jesus' hypostatic duality came to be emphasized during the later Middle Ages (see note 52), Joseph as smith, archetypical Master of Fire, simply may have had too much ideological potency to offer to fit comfortably merely as adjunct to more illustrious members of the Holy Family. Thus, any further pyrotechnic interests of the father guardian - cum - humble woodworker henceforth would be represented by, and strictly limited to, those of the domestic hearth.

\section{References Cited}

\section{Addison, Julia de Wolf Gibbs}

1908 Arts and Crafts in the Middle Ages. Boston: L. C. Page.

\section{Aelfric, Abbot of Eynsham}

1968 Homilies of Aelfric. A Supplementary Collection. Vol. 2. Ed. by John C. Pope. Oxford: Oxford University Press.

\section{Albright, W. F., and C.S. Mann}

1971 Matthew. Garden City: Doubleday. (The Anchor Bible, 26)

Bacon, Roger

1992 The Mirror of Alchemy. Composed by the ThriceFamous and Learned Fryer, Roger Bachon. Ed. by Stanton J. Linden. New York: Garland Publishing.

Barb, A. A.

1963 The Survival of Magic Arts. In: A. Momigliano (ed.), The Conflict between Paganism and Christianity in the Fourth Century; pp. 100-125. Oxford: Clarendon Press.

Batey, Richard A.

1984 "Is Not This the Carpenter?" New Testament Studies 30: 249-258.

Berger, Samuel

1893 Histoire de la Vulgate pendant les premiers siècles du Moyen Age. New York: Burt Franklin.

Biblia sacra

1969 Biblia sacra. Iuxta Vulgatam versionem. Vol. 2. Stuttgart: Württembergische Bibelanstalt.

$\rightarrow$ Blunt, Anthony

1938-39 Blake's "Ancient of Days." The Symbolism of the Compasses. Journal of the Warburg and Courtauld Institutes 2: 53-63.

Boenig, Robert

2000 Anglo-Saxon Spirituality. Selected Writings. New York: Paulist Press.

Bosworth, Joseph

1907 The Gospels. Gothic, Anglo-Saxon, Wycliffe, and Tyndale Versions. London: Gibbings.

\section{Brehaut, Ernest}

1912 An Encyclopedist of the Dark Ages. Isidore of Seville. New York: Longmans, Green, and Co.

Brown, Norman 0.

1947 Hermes the Thief. The Evolution of a Myth. Madison: University of Wisconsin Press.

\section{Bultmann, Rudolf}

1956 Primitive Christianity in Its Contemporary Setting. New York: Meridian Books.

\section{Burford, Alison}

1972 Craftsmen in Greek and Roman Society. Ithaca: Cornell University Press.

Caxton, William

1931 The Golden Legend or Lives of the Saints. London: J. M. Dent.

\section{Chadwick, Henry}

1967 The Early Church. Harmondsworth: Penguin Books.

\section{Chaney, William A.}

1967 Paganism to Christianity in Anglo-Saxon England. In: S. L. Thrupp (ed.), Early Medieval Society; pp. 67-83. New York: Appleton-Century-Crofts.

$\rightarrow$ Childs, S. Terry, and David Killick

1993 Indigenous African Metallurgy. Nature and Culture. Annual Review of Anthropology 22: 317-337.

Chorpenning, Joseph F.

1999 Commentary. Sermon Texts on Saint Francis by Francis de Sales. Toronto: Peregrina Publishing.

Cohen, Jeremy

1999 Living Letters of the Law. Ideas of the Jew in Medieval Christianity. Berkeley: University of California Press.

\section{Collins, Roger}

2000 Visigothic Spain 409-711. In: R. Carr (ed.), Spain. A History; pp. 39-62. Oxford: Oxford University Press.

Coogan, Michael D. (ed.)

2001 New Oxford Annotated Bible. Oxford: Oxford University Press. [3rd ed., New Revised Standard Version]

Cross, J. E. (ed.)

1996 Two Old English Apocrypha and Their Manuscript Source. The Gospel of Nicodemus and the Avenging of the Savior. Cambridge: Cambridge University Press.

\section{Cunliffe, Barry}

2001 Facing the Ocean. The Atlantic and Its Peoples 8000 B.C.-A.D. 1500. Oxford: Oxford University Press.

\section{Curtius, Ernst Robert}

1953 European Literature and the Latin Middle Ages. New York: Pantheon Books.

\section{Daniell, David}

2003 The Bible in English. Its History and Influence. New Haven: Yale University Press.

Daniélou, Jean

1973 Gospel Message and Hellinistic Culture. Philadelphia: Westminster Press.

Danker, Frederick William

2000 A Greek-English Lexicon of the New Testament and Other Early Christian Literature. Chicago: University of Chicago Press. [3rd. ed.]

Deasy, C. Philip

1937 St. Joseph in the English Mystery Plays. Washington: The Catholic University of America.

Detienne, Marcel, and Jean-Pierre Vernant

1978 Cunning Intelligence in Greek Culture and Society. New Jersey: Humanities Press. 
Díaz, Pablo C.

2001 Monasteries in a Peripheral Area. Seventh-Century Gallaecia. In: M. de Jong and F. Theuws (eds.), Topographies of Power in the Early Middle Ages; pp. 329-360. Leiden: E. J. Brill.

Díaz y Díaz, Manuel C.

1963 Aspects de la tradición de la Regula Isidori. Studia Monastica 5: 27-57.

Dickie, Matthew W.

1995 The Fathers of the Church and the Evil Eye. In: H. Maguire (ed.), Byzantine Magic; pp. 9-34. Washington: Dumbarton Oaks Research Library and Collection.

Dillon, John

1996 The Middle Platonists 80 B.C. to A.D. 220. New York: Cornell University Press.

Doresse, Jean

1960 The Secret Books of the Egyptian Gnostics. New York: The Viking Press.

\section{Dronke, Peter}

1974 Tradition and Innovation in Medieval Western ColourImagery. In: A. Portmann and R. Ritsema (eds.), The Realms of Colour; pp. 51-108. Leiden: E. J. Brill.

\section{Duby, Georges}

1968 Rural Economy and Country Life in the Medieval West. Columbia: University of South Carolina Press.

\section{Dunleavy, Gareth W.}

1960 Colum's Other Island. The Irish at Lindisfarne. Madison: University of Wisconsin Press.

\section{Eamon, William}

1983 Technology as Magic in the Late Middle Ages and Renaissance. Janus 70: 171-212.

Eco, Umberto

2004 History of Beauty. New York: Rizzoli.

Edsman, Carl-Martin

1949 Ignis Divinus. Lund: C. W. K. Gleerup. (Publications of the New Society of Letters at Lund, 34)

\section{Eliade, Mircea}

1959 The Sacred and the Profane. New York: Harcourt, Brace, and World.

1962 The Forge and the Crucible. New York: Harper and Row.

1964 Shamanism. Archaic Techniques of Ecstasy. Princeton: Princeton University Press.

Elliott, James Keith

1993 The Apocryphal New Testament. Oxford: Clarendon Press.

\section{$\rightarrow$ Emerson, Oliver $F$.}

1906 Legends of Cain, Especially in Old and Middle English. Publications of the Modern Language Association of America 21: 831-929.

Farmer, David Hugh

1992 The Oxford Dictionary of Saints. Oxford: Oxford University Press

Filas, Francis L

1962 Joseph. The Man Closest to Jesus. Boston: St. Paul Editions.

Flint, Valerie I. J.

1991 The Rise of Magic in Early Medieval Europe. Princeton: Princeton University Press.
Forbes, R. J.

1956 Metallurgy. In: C. Singer et al. (eds.), A History of Technology. Vol. 2; pp. 41-80. Oxford: The Clarendon Press.

1958 Studies in Ancient Technology. Vol. 6. Leiden: E. J. Brill

1964 Studies in Ancient Technology. Vol. 8. Leiden: E. J. Brill.

Forshall, Josiah, and Frederic Madden (eds.)

1850 The Holy Bible Containing the Old and New Testaments with the Apocryphal Books, in the Earliest English Versions ... by John Wycliffe and His Followers. Vol. 4. Oxford: Oxford University Press.

Foster, Frances A. (ed.)

1987 A Stanzaic Life of Christ. Millwood: Kraus Reprint. (Early English Text Society, 166) [London 1926]

Friedrichsen, G. W. S.

1926 The Gothic Version of the Gospels. London: Oxford University Press.

Furfey, Paul H.

1955 Christ as Tekton. The Catholic Biblical Quarterly 17: 204-215.

\section{Gantz, Timothy}

1993 Early Greek Myth. A Guide to Literary and Artistic Sources. Baltimore: Johns Hopkins University Press.

\section{Gasnier, Michel}

2000 Joseph the Silent. London: Scepter.

\section{Geoghegan, Arthur T.}

1945 The Attitude towards Labor in Early Christianity and Ancient Culture. Washington: The Catholic University of America Press.

Glacken, Clarence J.

1967 Traces on the Rhodian Shore. Berkeley: University of California Press.

Godfrey, John

1962 The Church in Anglo-Saxon England. Cambridge: Cambridge University Press.

Grant, Robert M.

1986 The Christ at the Creation. In: R. J. Hoffmann and G. A Larue (eds.), Jesus in History and Myth; pp. 157-167. Buffalo: Prometheus Books.

Graves, Robert, and Raphael Patai

1964 Hebrew Myths. The Book of Genesis. Garden City: Doubleday.

$\rightarrow$ Hahn, Cynthia

1984 Joseph as Ambrose's "Artist of the Soul" in "The Holy Family in Egypt" by Albrecht Dürer. Zeitschrift für Kunstgeschichte 47: 515-522.

1986 "Joseph Will Perfect Mary Enlighten and Jesus Save Thee." The Holy Family as Marriage Model in the Mérode Triptych. The Art Bulletin 68: 54-66.

Hale, Rosemary Drage

1996 Joseph as Mother. Adaptation and Appropriation in the Construction of Male Virtue. In: J. Carmi Parsons and B. Wheeler (eds.), Medieval Mothering; pp. 101-116. New York: Garland Publishing.

Hanson, K. C., and Douglas E. Oakman

1998 Palestine in the Time of Jesus. Social Structures and Social Conflicts. Minneapolis: Fortress Press. 


\section{Hardwick, Charles}

1858 The Gospel According to Saint Matthew in AngloSaxon and Northumbrian Versions. Cambridge: Cambridge University Press.

Heaney, Seamus

1980 Poems 1965-1975. New York: Farrar, Straus, and Giroux.

Heather, Peter, and John Matthews

1991 The Goths in the Fourth Century. Liverpool: Liverpool University Press.

Helms, Mary W.

1993 Craft and the Kingly Ideal. Art, Trade, and Power. Austin: University of Texas Press.

2002 Sacred Landscape and the Early Medieval European Cloister. Unity, Paradise, and the Cosmic Mountain. Anthropos 97: 435-453.

Herren, Michael W.

1980 On the Earliest Irish Acquaintance with Isidore of Seville. In: E. James (ed.), Visigothic Spain. New Approaches; pp. 243-250. Oxford: Clarendon Press.

Herren, Michael W., and Shirley Ann Brown

2002 Christ in Celtic Christianity. Britain and Ireland from the Fifth to the Tenth Century. Woodbridge: Boydell Press.

Hillgarth, J. N.

1962 Visigothic Spain and Early Christian Ireland. Proceedings of the Royal Irish Academy 62 (Sec. C): 167-194.

1980 Popular Religion in Visigothic Spain. In: E. James (ed.), Visigothic Spain. New Approaches; pp. 3-60. Oxford: Clarendon Press.

1984 Ireland and Spain in the Seventh Century. Peritia 3: 116.

Hock, Ronald F.

1995 The Infancy Gospels of James and Thomas. Santa Rosa: Polebridge Press.

Hogg, James, and Lawrence F. Powell (eds.)

1989 The Mirrour of the Blessed Lyf of Jesu Christ. 2 vols. Transl. by Nicholas Love. Salzburg: Institut für Anglistik und Amerikanistik, Universität Salzburg. (Analecta Cartusiana, 91)

Homer

1951 The Iliad of Homer. Transl. by Richard Lattimore. Chicago: University of Chicago Press.

1967 The Odyssey of Homer. Transl. by Richard Lattimore. New York: Harper and Row.

Hopkins, Arthur John

1934 Alchemy, Child of Greek Philosophy. New York: Columbia University Press.

Horn, Walter, and Ernest Born

1979 The Plan of St. Gall. A Study of the Architecture and Economy of, and Life in a Paradigmatic Carolingian Monastery. Vol. 2. Berkeley: University of California Press.

\section{Hugh of St. Victor}

1961 The Didascalicon of Hugh of St. Victor. Transl. by Jerome Taylor. New York: Columbia University Press.

Hughes, J. Donald

1983 How the Ancients Viewed Deforestation. Journal of Field Archaeology 10: 437-445.
Jacob, Edmond

1958 Theology of the Old Testament. New York: Harper and Row.

Jones, A. H. M.

1963 The Social Background of the Struggle between Paganism and Christianity. In: A. Momigliano (ed.), The Conflict between Paganism and Christianity in the Fourth Century; pp. 17-37. Oxford: Clarendon Press.

Jung, C. G.

1953 Psychology and Alchemy. London: Routledge and Kegan Paul.

Kardong, Terrence C.

1996 Benedict's Rule. A Translation and Commentary. Collegeville: Liturgical Press.

\section{Katzenellenbogen, Adolf}

1967 The Image of Christ in the Early Middle Ages. In: R. S. Hoyt (ed.), Life and Thought in the Early Middle Ages; pp. 66-84. Minneapolis: University of Minnesota Press.

\section{Keel, Othmar}

1978 The Symbolism of the Biblical World. Ancient Near Eastern Iconography and the Book of Psalms. New York: Seabury Press.

Kelly, John N. D.

1978 Early Christian Doctrines. New York: Harper and Row.

Kris, Ernst, and Otto Kurz

1979 Legend, Myth, and Magic in the Image of the Artist. New Haven: Yale University Press.

Lawrence, C. H.

1989 Medieval Monasticism. London: Longman. [2nd ed.]

\section{Leach, Edmund}

1969 Genesis as Myth and Other Essays. London: Jonathan Cape. (Cape Editions, 39)

Leach, Edmund, and D. Alan Aycock

1983 Structuralișt Interpretations of Biblical Myth. Cambridge: Cambridge University Press.

\section{Leander of Seville}

1969 The Training of Nuns. In: C. W. Barlow (trans.), The Fathers of the Church. Iberian Fathers. Vol. 1; pp. 183228. Washington: Catholic University of America Press.

\section{Leclercq, Jean}

1984 Otium Monasticum as a Context for Artistic Creativity. In: T. G. Verdon (ed.), Monasticism and the Arts; pp. 6380. Syracuse: Syracuse University Press.

Le Goff, Jacques

1977 Time, Work, and Culture in the Middle Ages. Chicago: University of Chicago Press.

1988a Medieval Civilization 400-1500. New York: Basil Blackwell.

1988b The Medieval Imagination. Chicago: University of Chicago Press.

Lewis, Robert E. (ed.)

1988 Middle English Dictionary. Part S. 9. Ann Arbor: University of Michigan Press.

2001 Middle English Dictionary. Part W. 8. Ann Arbor: University of Michigan Press.

\section{Lienhard, Joseph T.}

1999 St. Joseph in Early Christianity. Philadelphia: Saint Joseph's University Press. 
Long, Lynne

2001 Translating the Bible. From the 7th to the 17th Century. Aldershot: Ashgate.

Lönnrot, Elias (ed.)

1963 The Kalevala or Poems of the Kaleva District. Cambridge: Harvard University Press.

McNutt, Paula M.

1990 The Forging of Israel. Iron Technology, Symbolism, and Tradition in Ancient Society. Sheffield: Almond Press.

\section{Mayr-Harting, Henry}

1991 The Coming of Christianity to Anglo-Saxon England. University Park: Pennsylvania State University Press.

Meier, John P.

1991 A Marginal Jew. Rethinking the Historical Jesus. New York: Doubleday.

Meiggs, Russell

1982 Trees and Timber in the Ancient Mediterranean World. Oxford: Clarendon Press.

\section{Mellinkoff, Ruth}

1981 The Mark of Cain. Berkeley: University of California Press.

1993 Outcasts. Signs of Otherness in Northern European Art of the Late Middle Ages. Berkeley: University of California Press.

Migne, Jacques-Paul (ed.)

1844-64 Patrologiae cursus completus. Turnhout: BrepolsVerl.

Morris, Sarah P.

1992 Daidalos and the Origins of Greek Art. Princeton: Princeton University Press.

Mounce, William D.

1993 The Analytical Lexicon to the Greek New Testament. Grand Rapids: Zondervan.

\section{Murdoch, Brian}

2003 The Medieval Popular Bible. Expansions of Genesis in the Middle Ages. Cambridge: D. S. Brewer.

\section{Murray, Robert}

1975 Symbols of Church and Kingdom. A Study in Early Syriac Tradition. Cambridge: Cambridge University Press.

Neale, J. M., and R. F. Littledale

1883 A Commentary on the Psalms. Vol. 4: Psalm 119 to Psalm 150. London: Joseph Masters.

Nef, John U.

1987 Mining and Metallurgy in Medieval Civilization. In: M. M. Postan and E. Miller (eds.), The Cambridge Economic History of Europe. Vol. 2: Trade and Industry in the Middle Ages: pp.693-762. Cambridge: Cambridge University Press. [2nd ed.]

\section{Niditch, Susan}

1985 Chaos to Cosmos. Studies in Biblical Patterns of Creation. Chico: Scholars Press.

Nineham, D. E.

1963 The Gospel of St. Mark. Baltimore: Penguin Books.

Packer, James E.

1969 Roman Imperial Building (31 B.C. - A.D. 138). In: C. Roebuck (ed.), The Muses at Work. Arts, Crafts, and Professions in Ancient Greece and Rome; pp.36-59. Cambridge: The MIT Press.
Patai, Raphael

1994 The Jewish Alchemists. Princeton: Princeton University Press.

Plumpe, J. C.

1943 Vivum Saxum, Vivi Lapides. The Concept of "Living Stone" in Classical and Christian Antiquity. Traditio 1: $1-14$.

Ragusa, Isa, and Rosalie B. Green (eds.)

1961 Meditations on the Life of Christ. Princeton: Princeton University Press.

Richter, Michael

1988 Medieval Ireland. The Enduring Tradition. New York: St. Martin's Press.

Robins, Frederick W.

1953 The Smith. The Traditions and Lore of an Ancient Craft. New York: Rider.

Rogers, Rick

2000 Theophilus of Antioch. The Life and Thought of a Second-Century Bishop. Lanham: Lexington Books.

Ross, Ellen M.

1997 The Grief of God. Images of the Suffering Jesus in Late Medieval England. Oxford: Oxford University Press.

Russell, James C.

1994 The Germanization of Early Medieval Christianity. A Sociohistorical Approach to Religious Transformation. New York: Oxford University Press.

Salzberg, Hugh W.

1991 From Caveman to Chemist. Washington: American Chemical Society.

Sambursky, $S$.

1956 The Physical World of the Greeks. New York: MacMillan.

\section{Sarton, George}

1947 Introduction to the History of Science. Vol. 3, Part 1: Science and Learning in the Fourteenth Century. Baltimore: Williams and Wilkins.

\section{Schiller, Gertrud}

1971 Iconography of Christian Art. Vol. 1. Greenwich: New York Graphic Society.

\section{Sheingorn, Pamela}

1996 The Maternal Behavior of God. Divine Father as Fantasy Husband. In: J. Carmi Parsons and B. Wheeler (eds.) Medieval Mothering; pp. 77-100. New York: Garland Publishing.

Simonetti, Manlio

1994 Biblical Interpretation in the Early Church. An Historical Introduction to Patristic Exegesis. Edinburgh: T \& T Clark.

Simpson, D. P.

1968 Cassell's Latin Dictionary. Latin-English, English-Latin. London: Cassell.

Singer, Charles, et al. (eds.)

1956 A History of Technology. Vol. 2: The Mediterranean Civilizations and the Middle Ages c. 700 B.C. to A.D. 1500. Oxford: Clarendon Press.

\section{Smalley, Beryl}

1964 The Study of the Bible in the Middle Ages. Notre Dame: University of Notre Dame Press. 
$\rightarrow$ Smith, Cyril Stanley

1968 Matter versus Materials. A Historical View. Science 162: $637-644$

Smith, Morton

1978 Jesus the Magician. New York: Harper and Row.

Stratton-Pruitt, Suzanne L.

2002 Bartolomé Esteban Murillo (1617-1682). Paintings from American Collections. New York: Harry N. Abrams.

\section{Streitberg, Wilhelm}

1960 Die Gotische Bibel. Heidelberg: Carl Winter.

\section{Tatianus}

1966 Tatian. Lateinisch und altdeutsch mit ausführlichem Glossar. Hrsg. von Eduard Sievers. Paderborn: Ferdinand Schöningh Verlag.

Taylor, Jerome

1961 Introduction. In: Hugh of St. Victor, The Didascalicon of Hugh of St. Victor (Transl. by Jerome Taylor); pp. 1-39. New York: Columbia University Press.

Theophilus

1961 De Diuersis Artibus. The Various Arts. Transl. by C. R. Dodwell. London: Thomas Nelson and Sons.

1979 On Divers Arts. Transl. by John G. Hawthorne and Cyril Stanley Smith. New York: Dover Publications.

Theophilus of Antioch

1970 Ad Autolycum. Transl. by Robert M. Grant. Oxford: Clarendon Press.

Thompson, Edward A.

1966 The Visigoths in the Time of Ulfila. Oxford: Clarendor $\rightarrow$ White, Lynn Jr. Press.

Thomson, R. H. G.

1956 The Medieval Artisan. In: C. Singer, et al. (eds.); pp. 383-396.

Toller, T. Northcote (ed.)

1898 An Anglo-Saxon Dictionary Based on the Manuscript Collections of the Late Joseph Bosworth. London: Oxford University Press.
Treister, Michail Y.

1996 The Role of Metals in Ancient Greek History. Leiden: E. J. Brill.

Verdon, Timothy Gregory

1984 Monasticism and Christian Culture. In: T. G. Verdon (ed.), Monasticism and the Arts; pp. 1-28. Syracuse: Syracuse University Press.

Verhulst, Adriaan

2002 The Carolingian Economy. Cambridge: Cambridge University Press.

von Rad, Gerhard

1965 Old Testament Theology. Vol. 2. Transl. by D. M. G. Stalker. New York: Harper and Row.

Vries, Ad de

1974 Dictionary of Symbols and Imagery. Amsterdam: NorthHolland Publishing.

\section{Walbank, Frank William}

1987 Trade and Industry under the Later Roman Empire in the West. In: M. M. Postan and E. Miller (eds.), The Cambridge Economic History of Europe. Vol. 2: Trade and Industry in the Middle Ages; pp.74-131. Cambridge: Cambridge University Press. [2nd ed.]

\section{Warner, Marina}

1976 Alone of All Her Sex. The Myth and the Cult of the Virgin Mary. New York: Alfred A. Knopf.

Watson, E. W.

1989 Introduction. In: E. W. Watson and L. Pullan (transl.), St. Hilary of Poitiers. Select Works; pp.i-xcvi. Edinburgh: T \& T Clark. (A Select Library of Nicene and Post-Nicene Fathers, 2nd Series, 9)

1947 Natural Science and Naturalistic Art in the Middle Ages. The American Historical Review 52: 421 -435.

1962 Medieval Technology and Social Change. London: Oxford University Press.

1978 Medieval Religion and Technology. Collected Essays. Berkeley: University of California Press.

Wilson, Carolyn C.

2001 St. Joseph in Italian Renaissance Society and Art. Philadelphia: Saint Joseph's University Press. 